\title{
Expression of DNMTs and genomic DNA methylation in gastric signet ring cell carcinoma
}

\author{
MIAO HE ${ }^{1}$, JING FAN $^{2}$, RONG JIANG $^{3}$, WEI-XUE TANG $^{4}$ and ZI-WEI WANG ${ }^{1}$ \\ Departments of ${ }^{1}$ General Surgery and ${ }^{2}$ Emergency, The First Affiliated Hospital of Chongqing Medical University; \\ ${ }^{3}$ Laboratory of Stem Cell and Tissue Engineering, Institute of Basic Medicine of Chongqing Medical University; \\ ${ }^{4}$ Laboratory Research Center, The First Affiliated Hospital of Chongqing Medical University, Chongqing 400016, P.R. China
}

Received February 7, 2013; Accepted June 24, 2013

DOI: $10.3892 / \mathrm{mmr} .2013 .1566$

\begin{abstract}
The aim of the present study was to investigate the protein expression of DNA methyltransferases (DNMTs) and genomic DNA methylation status of genomes in gastric signet ring cell carcinoma (SRC). Immunohistochemistry was performed to analyze DNMT expression and methylated DNA immunoprecipitation microarray (MeDIP-chip) and MeDIP quantitative real-time PCR (MeDIP-qPCR) were performed to analyze the genomic DNA methylation status in gastric SRC tissue. An increase in DNMT1 and decrease in DNMT3A expression in SRC tissue was observed compared with matched non-cancerous tissue. However, expression of other DNMTs, DNMT2, DNMT3B and DNMT3L, was not found to differ significantly between carcinoma and control. The MeDIP-chip assay revealed that methylation of gene promoters and $\mathrm{CpG}$ islands in SRC was higher than those in matched control tissue. However, MeDIP-qPCR analysis demonstrated that specific tumor-related genes, including ABL2, FGF18, TRAF2, EGFL7 and RAB33A were aberrantly hypomethylated in SRC tissue. Results of the current study indicate that gastric SRC may produce complex patterns of aberrant DNA methylation and DNMT expression.
\end{abstract}

\section{Introduction}

Epigenetics is the study of inherited genetic changes that occur without altering the DNA sequence. DNA methylation is a mechanism of epigenetic change, with the most widely studied epigenetic alteration in human tumor cells being histone modification and chromatin remodeling (1). Human tumor cells exhibit aberrant DNA methylation patterns, including the hypermethylation of $\mathrm{CpG}$ islands in tumor suppressor genes

Correspondence to: Professor Zi-Wei Wang, Department of General Surgery, The First Affiliated Hospital of Chongqing Medical University, 1 Youyi Road, Yuanjiagang, Yuzhong, Chongqing 400016, P.R. China

E-mail: wangziwei571@163.com

Key words: DNA methyltransferases, gastric cancer, signet ring cell carcinoma, DNA methylation, epigenetics
(TSGs) and a global loss of DNA methylation in the genome (2). These changes are associated with the inactivation of TSGs and the activation of oncogenes or tumor promoter genes (TPGs), and may promote tumor progression (3). Abnormal expression of DNA methyltransferase (DNMT) may be important in the aberrant DNA methylation that occurs in tumors (4). Previous studies have identified elevated DNMT expression in tumors when compared with control tissue (5-8) and the overexpression of DNMT may contribute to tumor progression through the hypermethylation-mediated inactivation of TSGs in $\mathrm{CpG}$ islands (9). In the current study, expression of DNMTs (DNMT1, DNMT2, DNMT3A, DNMT3B and DNMT3L) and the DNA methylation pattern of the genome in gastric signet ring cell carcinoma (SRC) was investigated. Results of this study are likely to aid future epigenetic studies investigating SRC.

\section{Materials and methods}

Ethics statement. All experimental procedures were approved by the Ethics Committee of the First Affiliated Hospital of Chongqing Medical University (Chongqing, China). All patients provided written informed consent.

Clinical specimens. Twenty-eight pairs of human gastric SRC and matched non-cancerous tissue specimens (gastric mucosa tissue located $>5 \mathrm{~cm}$ from cancerous areas) were obtained from the Department of General Surgery of the First Affiliated Hospital of Chongqing Medical University. Characteristics of these tissues are presented in Table I. Tissues were fixed in formalin and embedded in paraffin for immunohistochemistry testing, and their diagnosis was confirmed by pathological analysis. For the methylated DNA immunoprecipitation microarray (MeDIP-chip) assay, one pair of gastric tissues was selected for pathological examination to verify that the selected cancerous and matched non-cancerous tissue specimens consisted of $>95 \%$ cancer and mucosal cells, respectively. In addition, five pairs of gastric tissues were selected for MeDIP quantitative real-time PCR (MeDIP-qPCR) assay to validate MeDIP-chip observations.

Immunohistochemistry. The streptavidin-peroxidase (SP) method was adopted and performed (7). Primary antibodies against DNMT1 (sc-20701), DNMT2 (sc-20702), DNMT3A 
Table I. Positive DNMT expression and differential clinical characteristics of gastric signet ring cell carcinoma, $\mathrm{n}(\%)$.

\begin{tabular}{|c|c|c|c|c|c|c|}
\hline Parameter & $\mathrm{n}$ & $\begin{array}{c}\text { DNMT1 } \\
\text { expression }(\%)\end{array}$ & $\begin{array}{c}\text { DNMT2 } \\
\text { expression (\%) }\end{array}$ & $\begin{array}{c}\text { DNMT3A } \\
\text { expression }(\%)\end{array}$ & $\begin{array}{c}\text { DNMT3B } \\
\text { expression }(\%)\end{array}$ & $\begin{array}{c}\text { DNMT3L } \\
\text { expression (\%) }\end{array}$ \\
\hline \multicolumn{7}{|l|}{ Gender } \\
\hline Male & 12 & $8(66.7)$ & $9(75.0)$ & $3(25.0)$ & $9(75.0)$ & $7(58.3)$ \\
\hline Female & 16 & $9(56.3)$ & $14(87.5)$ & $7(43.8)$ & $12(75.0)$ & $10(62.5)$ \\
\hline P-value & & 0.71 & 0.62 & 0.43 & 1.00 & 1.00 \\
\hline \multicolumn{7}{|l|}{ Age, years } \\
\hline$\geq 50$ & 13 & $7(53.8)$ & $10(76.9)$ & $5(38.5)$ & $10(76.9)$ & $7(53.8)$ \\
\hline$<50$ & 15 & $10(66.7)$ & $13(86.7)$ & $5(33.3)$ & $11(73.3)$ & $10(66.7)$ \\
\hline P-value & & 0.70 & 0.64 & 1.00 & 1.00 & 0.70 \\
\hline \multicolumn{7}{|l|}{ Location } \\
\hline Upper and middle & 13 & $6(46.2)$ & $11(84.6)$ & $5(38.5)$ & $11(84.6)$ & $7(53.8)$ \\
\hline lower & 15 & $11(73.3)$ & $12(80.0)$ & $5(33.3)$ & $10(66.7)$ & $10(66.7)$ \\
\hline P-value & & 0.25 & 1.00 & 1.00 & 0.40 & 0.70 \\
\hline \multicolumn{7}{|l|}{ Tumor size, $\mathrm{cm}$} \\
\hline$\geq 2$ & 16 & $12(75.0)$ & $13(81.3)$ & $7(43.8)$ & $13(81.3)$ & $11(68.8)$ \\
\hline$<2$ & 12 & $5(41.7)$ & $10(83.3)$ & $3(25.0)$ & $8(66.7)$ & $6(50.0)$ \\
\hline P-value & & 0.12 & 1.00 & 0.43 & 0.42 & 0.44 \\
\hline \multicolumn{7}{|l|}{ Depth of invasion } \\
\hline Mucosa and muscular & 5 & $1(20.0)$ & $4(80.0)$ & $2(40.0)$ & $2(40.0)$ & $2(40.0)$ \\
\hline Subserosa and serosa & 23 & $16(69.6)$ & $19(82.6)$ & $8(34.8)$ & $19(82.6)$ & $15(65.2)$ \\
\hline $\mathrm{P}$-value & & 0.06 & 1.00 & 1.00 & 0.08 & 0.35 \\
\hline \multicolumn{7}{|l|}{ Lymphnode metastasis } \\
\hline Yes & 17 & $14(82.4)$ & $13(76.5)$ & $5(29.4)$ & $14(82.4)$ & $11(64.7)$ \\
\hline No & 11 & $3(27.3)$ & $10(90.9)$ & $5(45.5)$ & $7(63.6)$ & $6(54.5)$ \\
\hline P-value & & $0.01^{*}$ & 0.62 & 0.44 & 0.38 & 0.70 \\
\hline \multicolumn{7}{|l|}{ TNM stage } \\
\hline I-II & 12 & $4(33.3)$ & $9(75.0)$ & $4(33.3)$ & $8(66.7)$ & $5(41.7)$ \\
\hline III-IV & 16 & $13(81.3)$ & $14(87.5)$ & $6(37.5)$ & $13(81.3)$ & $12(75.0)$ \\
\hline P-value & & $0.02^{*}$ & 0.62 & 1.00 & 0.42 & 0.12 \\
\hline \multicolumn{7}{|l|}{ H. pylori infection } \\
\hline Positive & 24 & $16(66.7)$ & $21(87.5)$ & $9(37.5)$ & $19(79.2)$ & $16(66.7)$ \\
\hline Negative & 4 & $1(25.0)$ & $2(50.0)$ & $1(25.0)$ & $2(50.0)$ & $1(25.0)$ \\
\hline P-value & & 0.27 & 0.14 & 1.00 & 0.25 & 0.27 \\
\hline
\end{tabular}

" $\chi^{2}$ test and Fisher's exact test, $\mathrm{P}<0.05$. DNMT, DNA methyltransferase; H. pylori, Helicobacter pylori.

(sc-20703), DNMT3B (sc-20704) and DNMT3L (sc-20705) were purchased from Santa Cruz Biotechnology, Inc. (Santa Cruz, CA, USA). The SP and DAB kits were obtained from Beijing Zhongshan Golden Bridge Biotechnology Co., Ltd. (Beijing, China).

Evaluation of staining. DNMT expression was assessed by scoring the staining intensity and stained proportion of the cell nucleus. Staining intensity was recorded as negative $=0$, light $=1$, moderate $=2$ or strong $=3$. The staining proportion was recorded as $1(\leq 25 \%), 2(\leq 50 \%), 3(\leq 75 \%)$ or $4(>75 \%)$. The two values were multiplied for each slide to produce a terminal score. If the score was higher in cancer cells than in matched control cells, this pair of tissues was marked with a '+' (corresponding to cancer cells that expressed elevated
DNMT levels). The opposite condition was marked with a '-' (corresponding to cancer cells that expressed reduced DNMT levels). If the scores were equal, the pair was marked with a ' 0 ' (corresponding to similar DNMT expression in cancer and control). Terminal scores of 0-3 were defined as negative expression; 4-12 were defined as positive expression.

MeDIP-chip assay. For the MeDIP-chip assay, the NimbleGen Human DNA Methylation 385K Promoter Plus CpG Island array was used (Roche Diagnostics GmbH, Mannheim Germany). This single array design, includes 28,226 CpG islands and all RefSeq gene promoter regions (between -800 and +200 bp of the transcription start sites), coated entirely with $\sim 385,000$ probes. Briefly, genomic DNA extraction and fragmentation, immunoprecipitation [using Biomag ${ }^{\mathrm{TM}}$ 
magnetic beads (Bangs Laboratories, Inc., Fisher, IN, USA) coupled to a mouse monoclonal antibody against 5-methylcytidine], whole genome amplification, DNA labeling and array hybridization, raw data scanning (with Axon GenePix 4000B microarray scanner; Axon 132 Instruments, Foster City, CA, USA), quality assessment of raw data, data normalization, data mapping to genomic features (transcripts and $\mathrm{CpG}$ islands) and summarizing for the selected gastric tissue, were performed by KangChen Bio-tech Inc. (Shanghai, China). Genes exhibiting differential DNA methylation in $\mathrm{CpG}$ islands between SRC and control tissue from the genome (based on the results supplied by KangChen Bio-tech) were separated and investigated for tumor-associated genes.

$M e D I P-q P C R$. Genomic DNA was extracted from 5 pairs of gastric tissue using a DNeasy Blood and Tissue kit (Qiagen, Hilden, Germany) and sonicated to random fragments of 200-1,000 bp with a Bioruptor sonicator (Diagenode, Denville, NJ, USA). Sonicated DNA fragments were divided in two, one part was used as input (normalized control) and the other was prepared for MeDIP. MeDIP was performed using Biomag magnetic beads coupled to a mouse monoclonal antibody against 5-methylcytidine. The immunoprecipitated DNA was eluted and purified by phenol chloroform extraction and ethanol precipitation for the subsequent qRT-PCR. qRT-PCR was conducted on an ABI Prism 7900 system (Applied Biosystems, Foster City, CA, USA) using PCR master mix (Qiagen) and specific primers were denatured at $95^{\circ} \mathrm{C}$ for $10 \mathrm{~min}$ followed by 40 cycles of $95^{\circ} \mathrm{C}$ for $10 \mathrm{sec}$ and $60^{\circ} \mathrm{C}$ for $60 \mathrm{sec}$. Following this, the comparative $\Delta \Delta \mathrm{Ct}$ method was performed. Each MeDIP DNA Ct value was normalized against the input DNA value for the same qRT-PCR assay $(\Delta \mathrm{Ct})$ to account for chromatin sample preparation differences. The input percentage for each MeDIP fraction was calculated using the following formula: input percentage $=2\left(\mathrm{Ct}_{\text {input }}-\mathrm{Ct}_{\mathrm{MeDIP}}\right) \times \mathrm{Fd} \times 100 . \mathrm{Fd}$ represents the input dilution factor $(1 / 5)$. The input percentage values represent the DNA methylation levels of validated genes in this assay.

Statistical analysis. Standard statistical analysis was performed using the SPSS version 17.0 (SPSS, Inc., Chicago, IL, USA). The Wilcoxon signed-rank test (for immunohistochemistry analysis), $\chi^{2}$ test, Fisher's exact test (for association analysis between DNMT expression and clinical parameters of SRC) and paired t-test (for MeDIP-qPCR) were used in this study. $\mathrm{P}<0.05$ was considered to indicate a statistically significant difference.

\section{Results}

Expression of DNMT in gastric SRC tissue. Gastric SRC and matched mucosal tissue expressed DNMT proteins (Fig. 1). Notably, DNMT protein distribution was observed primarily in the nucleus of cancerous tissue and in the nucleus and cytoplasm of control tissue. DNMT expression in non-cancerous tissue was primarily focused on the proliferating zone of gastric mucosa. DNMTs perform DNA methylation in the nucleus; thus, nuclear staining was investigated. DNMT1 expression was elevated and DNMT3A expression was decreased in gastric

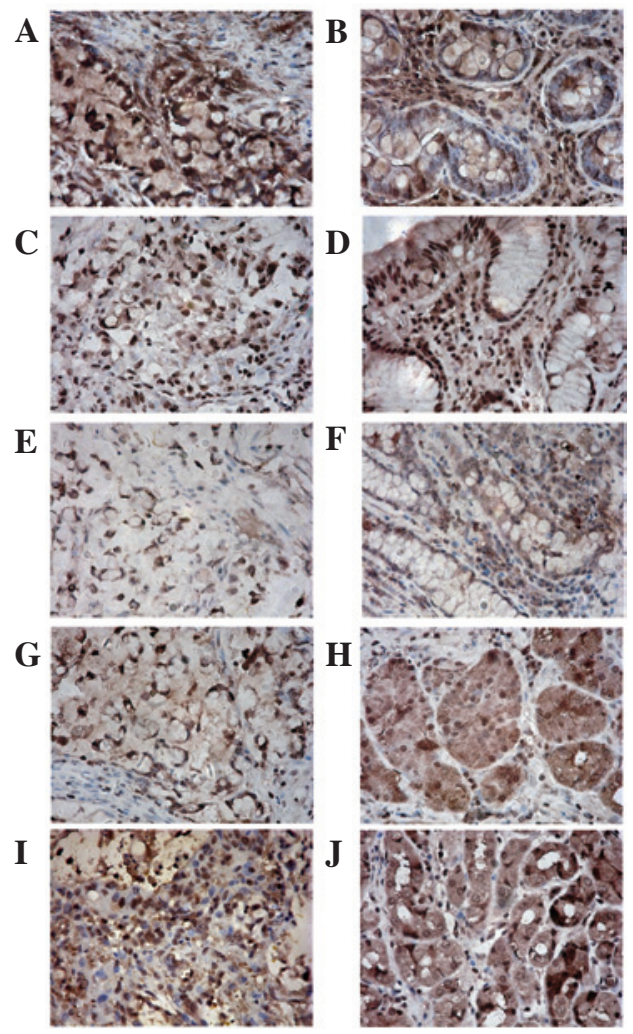

Figure 1. DNMT expression in gastric signet ring cell carcinoma and matched mucosa tissues (magnification, x200). Expression of (A) DNMT1 in carcinoma; (B) DNMT1 in mucosa tissue; (C) DNMT2 in carcinoma; (D) DNMT2 in mucosa tissue; (E) DNMT3A in carcinoma; (F) DNMT3A in mucosa tissue; $(\mathrm{G})$ DNMT3B in carcinoma; $(\mathrm{H})$ DNMT3B in mucosa tissue; (I) DNMT3L in carcinoma; and (J) DNMT3L in mucosa tissue. DNMT, DNA methyltransferase.

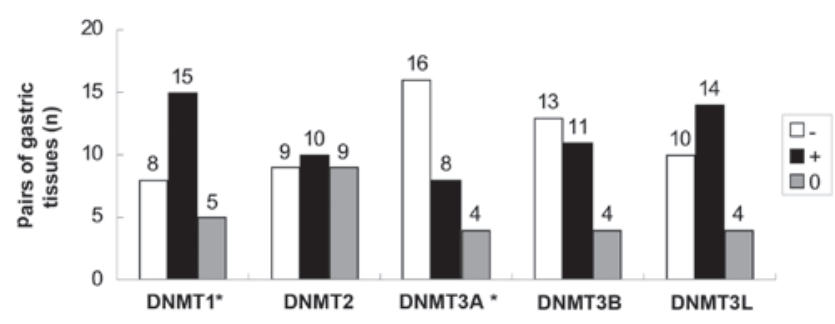

Figure 2. DNMT expression in gastric SRC and matched mucosal tissue by nuclear staining analysis. '-': lower in carcinoma than matched mucosa. '+': elevated in carcinoma than matched mucosa. ' 0 ': similar in carcinoma and in matched mucosa. DNMT1 expression was higher in gastric SRC than in matched tissues. DNMT3A expression was lower in SRC than in matched tissues ( $\mathrm{P}<0.05$, Wilcoxon signed-rank test). Differences were not significant for other DNMTs (P>0.05, Wilcoxon signed-rank test). DNMT, DNA methyltransferase; SRC, signet ring cell carcinoma.

SRC when compared with matched control tissue (Fig. 2). However, expression of other DNMTs did not differ significantly between cancerous and non-cancerous tissue.

Correlation between DNMT expression and clinical characteristics of gastric SRC. According to the TNM classification of malignant tumors, expression of DNMT1 was associated with lymph node metastasis in gastric SRC (Table I). SRC samples with features of lymph node metastasis and attributes of late TNM classification were found to express DNMT1 protein at 
Table II. Overview of MeDIP-chip data.

\begin{tabular}{lcr}
\hline Classification & CpG islands $(\%)$ & Gene promoters $(\%)$ \\
\hline Hypermethylation only in cancer & $2,832(10.03)$ & $1,541(8.55)$ \\
Hypermethylation only in control & $2,273(8.05)$ & $913(5.06)$ \\
Hypermethylation in cancer and control & $1,943(6.88)$ & $736(4.08)$ \\
Hypomethylation in cancer and control & $21,178(75.03)$ & $14,838(82.31)$ \\
Hypermethylation in cancer & $4,775(16.92)$ & $2,277(12.63)$ \\
Hypermethylation in control & $4,216(14.94)$ & $1,649(9.15)$ \\
Total & 28,226 & 18,028
\end{tabular}

MeDIP, methylated DNA immunoprecipitation microarray.

Table III. Differential DNA methylation of tumor-related genes between SRC and control.

\begin{tabular}{|c|c|c|}
\hline Classification & TSG (ref.) & Oncogene and TPG (ref.) \\
\hline Hypermethylation only in cancer & $\begin{array}{l}\text { BCL2L11 (10) } \\
\text { BRMS-1 (11) } \\
\text { CARS (12) } \\
\text { CDKN1C (13) } \\
\text { CDKN2A (14) } \\
\text { DLC-1 (15) } \\
\text { ING-1 (16) } \\
\text { OVCA2 (17) } \\
\text { RASD1 (18) } \\
\text { RB-1 (19) } \\
\text { SYK (20) }\end{array}$ & $\begin{array}{l}\text { APCDD1 (24) } \\
\text { BCL11A (25) } \\
\text { JUN (26) } \\
\text { LYN (27) } \\
\text { MYB (28) } \\
\text { MYCL1 (29) } \\
\text { REL (30) } \\
\text { SRC (31) } \\
\text { WNT4 (32) } \\
\text { WNT9A (32) } \\
\text { WNT10A (32) } \\
\text { WNT11 (33) } \\
\text { KRAS (34) } \\
\text { VEGFA (35) } \\
\text { RAB6A (36) } \\
\text { RAB8A (37) } \\
\text { RAB27A (38) } \\
\text { RAB32 (39) }\end{array}$ \\
\hline Hypomethylation only in cancer & $\begin{array}{l}\text { APAF1 (21) } \\
\text { CAV2 (22) } \\
\text { RASSF1 (23) }\end{array}$ & $\begin{array}{l}\text { RAB33A (36) } \\
\text { ABL2 (40) } \\
\text { FGF18 (41) } \\
\text { EGFL7 (42) } \\
\text { FYN (43) } \\
\text { MYCNOS (44) } \\
\text { RAB3A (45) } \\
\text { TRAF2 (46) } \\
\text { WNT3A (47) }\end{array}$ \\
\hline
\end{tabular}

SRC, signet ring cell carcinoma; TSG, tumor suppressor gene; TPG, tumor promotor gene.

a higher level than control samples. There was no association noted in other DNMT expression and demographic variables of the carcinoma.

Comparison of genomic DNA methylation between gastric SRC and matched control tissue. DNMT proteins in the selected pair of gastric tissues were scored by immunohistochemistry assay as follows: DNMT1 ‘+'; DNMT2 '0’; DNMT3A '-'; DNMT3B ‘+'; and DNMT3L '-'. In carcinoma and matched mucosal tissue, characteristics of interest included local hypermethylation and global hypomethylation of genomic DNA. Specific CpG islands and gene promoters were hypermethylated only in carcinoma 
Table IV. Primer sequences of validation genes.

Gene name

Primer sequences

Length (bp)

$\begin{array}{ll}\text { ABL2 } & \text { F:5'ATTTGACAGGTGGAGGTGGGAT3' } \\ & \text { R:5'CGCTGCTTGAGGTCTTTCGTC3' } \\ \text { FGF18 } & \text { F:5'GGCTGGGAAACTCCACGAT3' } \\ & \text { R:5'CCACATTCGCTACTCGCACT3' } \\ \text { TRAF2 } & \text { F:5'GGAGAATCGCTTGAACCCG3' } \\ & \text { R:5'GTGTGCTAATCTACTGGGTTGTGC3' } \\ \text { EGFL7 } & \text { F:5'CTGGTTCTGGCTGTTTTGG3' } \\ & \text { R:5'ATGCTCCGTCCTGGGTAATC3' } \\ \text { RAB33A } & \text { F:5'ACCAGACAAGACTGAAGCCACC3' } \\ & \text { R:5'CGACAACCGCTAGAGCTATGC3' }\end{array}$

154

Table V. Input percentage value of validation genes in signet ring cell carcinoma and control tissues, MeDIP-qPCR.

\begin{tabular}{llr}
\hline Gene name & Carcinoma tissue & Control tissue \\
\hline ABL2 & $0.0114 \pm 0.00408^{\mathrm{a}}$ & $1.1698 \pm 0.22944$ \\
FGF18 & $0.0115 \pm 0.00125^{\mathrm{a}}$ & $1.3419 \pm 0.15275$ \\
TRAF2 & $0.8152 \pm 0.20569^{\mathrm{a}}$ & $3.5592 \pm 0.40797$ \\
EGFL7 & $0.3557 \pm 0.06140^{\mathrm{a}}$ & $1.9956 \pm 0.31949$ \\
RAB33A & $0.0465 \pm 0.00735^{\mathrm{a}}$ & $2.1858 \pm 0.26880$ \\
\hline
\end{tabular}

${ }^{\mathrm{a}} \mathrm{P}<0.05$, vs. control; paired t-test; mean $\pm \mathrm{SD}, \mathrm{n}=5$; MeDIP, methylated DNA immunoprecipitation.

tissue, whereas other $\mathrm{CpG}$ islands and gene promoters were hypermethylated only in matched mucosa tissue (Table II), indicating that these DNA sequences were hypomethylated only in carcinoma tissue. Following a comprehensive analysis involving separation of genes exhibiting differential DNA methylation in promoters between the carcinoma and control from the genome, and searching for tumor-related genes in these separating genes, gastric SRC was observed to contain hypermethylated and hypomethylated TSGs, oncogenes and tumor-promoter genes (TPGs; Table III) (10-47).

Validation of the abnormally hypomethylated genes in gastric SRC by MeDIP-qPCR. ABL2, FGF18, TRAF2, EGFL7 and RAB33A were selected as validation genes. Their primer sequences are presented in Table IV. Using MeDIP-qPCR, the input percentage values of these genes were observed to be significantly lower in SRC than in matched mucosal tissue (Table V), indicating that the DNA was abnormally hypomethylated in gastric SRC compared with matched control tissue. This result was in agreement with the MeDIP-chip observations. The input percentage values of these genes the in negative control (non-immune serum) were $<0.01$.

\section{Discussion}

According to the World Health Organization, there are four predominant histological types of gastric adenocarcinoma, papillary, tubular, mucinous and SRC. SRC is characterized by the histological appearance of signet ring cells, a large vacuole full of mucin in the cytoplasm displacing the nucleus to the periphery. This adenocarcinoma originates from the undifferentiated stem cells at the gastric gland neck in gastric lamina propria and accounts for 3.14-29\% of gastric cancer (48). SRC is a poorly differentiated adenocarcinoma with rapid progression and poor prognosis. To date, the etiology of SRC is unclear and therapy is mainly dependent on surgical procedures (SRC is non-responsive to chemotherapy).

Epigenetic alterations, including promoter hypermethylation, lead to chromatin remodeling and the silencing of tumor-related genes, and are crucial in tumor progression (49). DNA methylation is catalyzed mainly by DNMTs, including DNMT1, DNMT2, DNMT3A, DNMT3B and DNMT3L (50-53). Previous studies have indicated that overexpression of DNMT may contribute to tumor progression through hypermethylation-mediated TSG inactivation in $\mathrm{CpG}$ islands. We hypothesized that overexpression of DNMT also may be detected in SRC.

In the current study, it was observed that gastric SRC and matched mucosal tissue expressed DNMT proteins. DNMT expression in non-cancerous tissue was primarily focused on the proliferating zones of gastric mucosa. An abnormal overexpression of DNMT1 was observed when nuclear staining was taken into consideration in SRC tissue compared with matched mucosal tissue. By contrast, DNMT3A expression in SRC was not significant compared with that in matched controls. For the remaining DNMTs, no expression difference between SRC and control tissue was noted. The observations indicate that overexpression of DNMT in SRC tissue was specific to DNMT1. 
Following association analysis between the demographic variables and DNMT expression of SRC, positive expression of DNMT1 was associated with lymph node metastasis and late TNM stages of SRC, indicating a potential role of DNMT1 proteins in promoting SRC progression. It was hypothesized that DNMT1 may function in a similar manner to an oncogene in SRC. Considering no association was noted between DNMT3A and clinical characteristics of SRC, the hypothesis that SRC expresses a lower level of DNMT3A compared with control requires further investigation. DNMT proteins were distributed in the nucleus and cytoplasm, particularly in the proliferative zones of normal gastric mucosa. It is not yet clear if there are unknown substances in the cytoplasm that may cross-react with DNMT antibodies or if DNMT proteins function in the cytoplasm. Further investigation is required to confirm this.

The MeDIP-chip assay revealed local hypermethylation and global hypomethylation of genomic DNA in SRC and matched mucosal tissue. The number of hypermethylated $\mathrm{CpG}$ islands and gene promoters in SRC were increased compared with those in control mucosa (4,775 vs. 4,216 and 2,277 vs. 1,649, respectively; Table II). This observation indicated that DNA methylation of the genome increased in SRC compared with matched controls. Notably, in gastric SRC, hypermethylated and hypomethylated TSGs, oncogenes and TPGs were observed. The subsequent MeDIP-qPCR assay validated specific MeDIP-chip results. Tumor-related genes, ABL2, FGF18, TRAF2, EGFL7 and RAB33A, were abnormally hypomethylated in SRC tissue compared with matched controls. This observation is an addition to the traditional DNA methylation theory, which focuses on the hypermethylation of TSG in tumors and indicates that the aberrant DNA methylation pattern of the SRC genome is complex. Similar observations were also demonstrated in liver and pancreatic cancer $(54,55)$. Specific tumors exhibit abnormal hypomethylation of TPGs and oncogenes $(56,57)$ and overexpression of these genes due to hypomethylation, is potentially another epigenetic mechanism for uncontrollable cancer cell proliferation (55).

In conclusion, gastric SRCs express elevated DNMT1 protein and reduced DNMT3A protein compared with matched gastric mucosa. A difference between genomic DNA methylation between SRC and control (gastric mucosa) samples exists, however, it appears to be complex since it is not limited to hypermethylation of TSGs.

To date, there has been encouraging progression in the understanding of the role of DNA methylation in tumors. However, clinical applications based on DNA methylation theory for diagnosis and treatments of tumors remain scarce. Further investigation is required to investigate the role of DNMT inhibitors, including 5-aza-2'-deoxycytidine, in inhibiting cancer cell proliferation.

\section{References}

1. Esteller M: Cancer Epigenetics for the 21st Century: What's Next? Genes Cancer 2: 604-606, 2011.

2. Daniel FI, Cherubini K, Yurgel LS, de Figueiredo MA and Salum FG: The role of epigenetic transcription repression and DNA methyltransferases in cancer. Cancer 117: 677-687, 2011.

3. Bender CM, Pao MM and Jones PA: Inhibition of DNA methylation by 5-aza-2'-deoxycytidine suppresses the growth of human tumor cell lines. Cancer Res 58: 95-101, 1998.
4. Fang JY, Cheng ZH, Chen YX, Lu R, Yang L, Zhu HY and Lu LG: Expression of Dnmt1, demethylase, MeCP2 and methylation of tumor-related genes in human gastric cancer. World J Gastroenterol 10: 3394-3398, 2004.

5. Choi MS, Shim YH, Hwa JY, Lee SK, Ro JY, Kim JS and Yu E: Expression of DNA methyltransferases in multistep hepatocarcinogenesis. Hum Pathol 34: 11-17, 2003.

6. Ding WJ, Fang JY, Chen XY and Peng YS: The expression and clinical significance of DNA methyltransferase proteins in human gastric cancer. Dig Dis Sci 53: 2083-2089, 2008.

7. Peng DF, Kanai Y, Sawada M, Ushijima S, Hiraoka N, Kosuge T and Hirohashi S: Increased DNA methyltransferase 1 (DNMT1) protein expression in precancerous conditions and ductal carcinomas of the pancreas. Cancer Sci 96: 403-408, 2005.

8. Arai E, Kanai Y, Ushijima S, Fujimoto H, Mukai K and Hirohashi S: Regional DNA hypermethylation and DNA methyltransferase (DNMT) 1 protein overexpression in both renal tumors and corresponding nontumorous renal tissues. Int $\mathrm{J}$ Cancer 119: 288-296, 2006

9. Vertino PM, Yen RW, Gao J and Baylin SB: De novo methylation of $\mathrm{CpG}$ island sequences in human fibroblasts overexpressing DNA (cytosine-5-)-methyltransferase. Mol Cell Biol 16: 4555-4565, 1996

10. Klotz DM, Nelson SA, Kroboth K, Newton IP, Radulescu S, Ridgway RA, Sansom OJ, Appleton PL and Näthke IS: The microtubule poison vinorelbine kills cells independently of mitotic arrest and targets cells lacking the APC tumour suppressor more effectively. J Cell Sci 125: 887-895, 2012.

11. Ohta S, Lai EW, Pang AL, Brouwers FM, Chan WY, Eisenhofer G, de Krijger R, Ksinantova L, Breza J, Blazicek P, Kvetnansky R, Wesley RA and Pacak K: Downregulation of metastasis suppressor genes in malignant pheochromocytoma. Int J Cancer 114: 139-143, 2005.

12. Gilham DE, Debets R, Pule M, Hawkins RE and Abken H: CAR-T cells and solid tumors: tuning T cells to challenge an inveterate foe. Trends Mol Med 18: 377-384, 2012.

13. Riccio A and Cubellis MV: Gain of function in CDKN1C. Nat Genet 44: 737-738, 2012.

14. Harinck F, Kluijt I, van der Stoep N, Oldenburg RA, Wagner A, Aalfs CM, Sijmons RH, Poley JW, Kuipers EJ, Fockens P, van Os TA and Bruno MJ: Indication for CDKN2A-mutation analysis in familial pancreatic cancer families without melanomas. J Med Genet 49: 362-365, 2012.

15. Guan CN, Zhang PW, Lou HQ, Liao XH and Chen BY: DLC-1 expression levels in breast cancer assessed by qRT-PCR are negatively associated with malignancy. Asian Pac J Cancer Prev 13: 1231-1233, 2012.

16. Liu J, Lin Y, Yang H, Deng Q, Chen G and He J: The expression of p33(ING1), p53 and autophagy-related gene Beclin1 in patients with non-small cell lung cancer. Tumour Biol 32: 1113-1121, 2011.

17. Schultz DC, Vanderveer L, Berman DB, Hamilton TC, Wong AJ and Godwin AK: Identification of two candidate tumor suppressor genes on chromosome 17p13.3. Cancer Res 56: 1997-2002, 1996.

18. Vaidyanathan G, Cismowski MJ, Wang G, Vincent TS, Brown KD and Lanier SM: The Ras-related protein AGS1/RASD1 suppresses cell growth. Oncogene 23: 5858-5863, 2004.

19. Berman SD, Calo E, Landman AS, Danielian PS, Miller ES, West JC, Fonhoue BD, Caron A, Bronson R, Bouxsein ML, Mukherjee S and Lees JA: Metastatic osteosarcoma induced by inactivation of $\mathrm{Rb}$ and $\mathrm{p} 53$ in the osteoblast lineage. Proc Natl Acad Sci USA 105: 11851-11856, 2008.

20. Kanwal S, Kayani MA and Faryal R: Identification of novel SNPs in SYK gene of breast cancer patients: computational analysis of SNPs in the 5'UTR. Mol Biol Rep 39: 8345-8351, 2012.

21. Behjati R, Kawai K, Inadome Y, Kano J, Akaza H and Noguchi M: APAF-1 is related to an undifferentiated state in the testicular germ cell tumor pathway. Cancer Sci 102: 267-274, 2011.

22. Chêne L, Giroud C, Desgrandchamps F, Boccon-Gibod L, Cussenot $\mathrm{O}$, Berthon $\mathrm{P}$ and Latil A: Extensive analysis of the 7q31 region in human prostate tumors supports TES as the best candidate tumor suppressor gene. Int J Cancer 111: 798-804, 2004.

23. da Costa Prando E, Cavalli LR and Rainho CA: Evidence of epigenetic regulation of the tumor suppressor gene cluster flanking RASSF1 in breast cancer cell lines. Epigenetics 6: $1413-1424,2011$.

24. Takahashi M,Fujita M, Furukawa Y, Hamamoto R, Shimokawa T, Miwa N, Ogawa M and Nakamura Y: Isolation of a novel human gene, APCDD1, as a direct target of the beta-Catenin/T-cell factor 4 complex with probable involvement in colorectal carcinogenesis. Cancer Res 62: 5651-5656, 2002. 
25. Agueli C, Cammarata G, Salemi D, Dagnino L, Nicoletti R, La Rosa M, Messana F, Marfia A, Bica MG, Coniglio ML, Pagano M, Fabbiano F and Santoro A: 14q32/miRNA clusters loss of heterozygosity in acute lymphoblastic leukemia is associated with up-regulation of BCL11a. Am J Hematol 85: 575-578, 2010.

26. Zhang X, Liu H, Li B, Huang P, Shao J and He Z: Tumor suppressor BLU inhibits proliferation of nasopharyngeal carcinoma cells by regulation of cell cycle, c-Jun N-terminal kinase and the cyclin D1 promoter. BMC Cancer 12: 267, 2012

27. Wheeler SE, Morariu EM, Bednash JS, Otte CG, Seethala RR, Chiosea SI and Grandis JR: Lyn kinase mediates cell motility and tumor growth in EGFRvIII-expressing head and neck cancer. Clin Cancer Res 18: 2850-2860, 2012.

28. Persson M andrén Y, Moskaluk CA, Frierson HF Jr, Cooke SL, Futreal PA, Kling T, Nelander S, Nordkvist A, Persson F and Stenman G: Clinically significant copy number alterations and complex rearrangements of MYB and NFIB in head and neck adenoid cystic carcinoma. Genes Chromosomes Cancer 51: 805-817, 2012

29. Xiong F, Wu C, Chang J, Yu D, Xu B, Yuan P, Zhai K, Xu J, Tan W and Lin D: Genetic variation in an miRNA-1827 binding site in MYCL1 alters susceptibility to small-cell lung cancer. Cancer Res 71: 5175-5181, 2011.

30. Gilmore TD and Gerondakis S: The c-Rel transcription factor in development and disease. Genes Cancer 2: 695-711, 2011

31. Zhang L, Teng Y, Zhang Y, Liu J, Xu L, Qu J, Hou K, Yang X, Liu Y and Qu X: C-Src-mediated RANKL-induced breast cancer cell migration by activation of the ERK and Akt pathway. Oncol Lett 3: 395-400, 2012.

32. Memarian A, Hojjat-Farsangi M, Asgarian-Omran H, Younesi V, Jeddi-Tehrani M, Sharifian RA, Khoshnoodi J, Razavi SM, Rabbani H and Shokri F: Variation in WNT genes expression in different subtypes of chronic lymphocytic leukemia. Leuk Lymphoma 50: 2061-2070, 2009.

33. Dwyer MA, Joseph JD, Wade HE, Eaton ML, Kunder RS, Kazmin D, Chang CY and McDonnell DP: WNT11 expression is induced by estrogen-related receptor alpha and beta-catenin and acts in an autocrine manner to increase cancer cell migration. Cancer Res 70: 9298-9308, 2010.

34. Tanic M, Yanowsky K, Rodriguez-Antona C, Andrés R, Márquez-Rodas I, Osorio A, Benitez J and Martinez-Delgado B: Deregulated miRNAs in hereditary breast cancer revealed a role for miR-30c in regulating KRAS oncogene. PLoS One 7: e38847, 2012.

35. Qiu JF, Zhang ZQ, Wang Y and You J: Lentivirus-mediated RNAi knockdown of VEGFA in RKO colorectal cancer cells decreases tumor formation and growth in vitro and in vivo. Int J Clin Exp Pathol 5: 290-298, 2012.

36. Seyhan AA, Varadarajan U, Choe S, Liu W and Ryan TE: A genome-wide RNAi screen identifies novel targets of neratinib resistance leading to identification of potential drug resistant genetic markers. Mol Biosyst 8: 1553-1570, 2012

37. Shen DW and Gottesman MM: RAB 8 enhances TMEM205-mediated cisplatin resistance. Pharm Res 29: 643-650, 2012

38. Wang JS, Wang FB, Zhang QG, Shen ZZ and Shao ZM: Enhanced expression of Rab27A gene by breast cancer cells promoting invasiveness and the metastasis potential by secretion of insulin-like growth factor-II. Mol Cancer Res 6: 372-382, 2008.

39. Shibata D, Mori Y, Cai K, Zhang L, Yin J, Elahi A, Hamelin R, Wong YF, Lo WK, Chung TK, Sato F, Karpeh MS Jr and Meltzer SJ: RAB32 hypermethylation and microsatellite instability in gastric and endometrial adenocarcinomas. Int J Cancer 119: 801-806, 2006.

40. Cong XL, Li B, Yang RC, Feng SZ, Chen SJ and Han ZC: Enhanced growth suppression of Philadephial leukemia cells by targeting bcr3/abl2 and VEGF through antisense strategy. Leukemia 19: 1517-1524, 2005.
41. Sonvilla G, Allerstorfer S, Stättner S, Karner J, Klimpfinger M, Fischer H, Grasl-Kraupp B, Holzmann K, Berger W, Wrba F, Marian B and Grusch M: FGF18 in colorectal tumour cells: autocrine and paracrine effects. Carcinogenesis 29: 15-24, 2008.

42. Delfortrie S, Pinte S, Mattot V, Samson C, Villain G, Caetano B, Lauridant-Philippin G, Baranzelli MC, Bonneterre J, Trottein F, Faveeuw C and Soncin F: Egfl7 promotes tumor escape from immunity by repressing endothelial cell activation. Cancer Res 71: 7176-7186, 2011.

43. Schenone S, Brullo C, Musumeci F, Biava M, Falchi F and Botta M: Fyn kinase in brain diseases and cancer: the search for inhibitors. Curr Med Chem 18: 2921-2942, 2011.

44. Jacobs JF, van Bokhoven H, van Leeuwen FN, Hulsbergen-van de Kaa CA, de Vries IJ, Adema GJ, Hoogerbrugge PM and de Brouwer AP: Regulation of MYCN expression in human neuroblastoma cells. BMC Cancer 9: 239, 2009.

45. Lankat-Buttgereit B, Fehmann HC, Hering BJ, Bretzel RG and Göke B: Expression of the ras-related rab3a gene in human insulinomas and normal human pancreatic islets. Pancreas 9: 434-438, 1994

46. Jang KW, Lee KH, Kim SH, Jin T, Choi EY, Jeon HJ, Kim E, Han YS and Chung JH: Ubiquitin ligase CHIP induces TRAF2 proteasomal degradation and $\mathrm{NF}-\mathrm{\kappa B}$ inactivation to regulate breast cancer cell invasion. J Cell Biochem 112: 3612-3620, 2011.

47. Kawaguchi-Ihara N, Murohashi I, Nara N and Tohda S: Promotion of the self-renewal capacity of human acute leukemia cells by Wnt3A. Anticancer Res 28: 2701-2704, 2008.

48. Charlton A, Blair V, Shaw D, Parry S, Guilford P and Martin IG Hereditary diffuse gastric cancer: predominance of multiple foci of signet ring cell carcinoma in distal stomach and transitional zone. Gut 53: 814-820, 2004

49. Rountree MR, Bachman KE, Herman JG and Baylin SB: DNA methylation, chromatin inheritance and cancer. Oncogene 20: 3156-3165, 2001.

50. Schaefer M, Hagemann S, Hanna K and Lyko F: Azacytidine inhibits RNA methylation at DNMT2 target sites in human cancer cell lines. Cancer Res 69: 8127-8132, 2009.

51. Ooi SK, Qiu C, Bernstein E, Li K, Jia D, Yang Z, Erdjument-Bromage H, Tempst $\mathrm{P}$, Lin SP, Allis CD, Cheng $\mathrm{X}$ and Bestor TH: DNMT3L connects unmethylated lysine 4 of histone $\mathrm{H} 3$ to de novo methylation of DNA. Nature 448: 714-717, 2007.

52. Bourc'his D, Xu GL, Lin CS, Bollman B and Bestor TH: Dnmt3L and the establishment of maternal genomic imprints. Science 294: 2536-2539, 2001.

53. Jia D, Jurkowska RZ, Zhang X, Jeltsch A and Cheng X: Structure of Dnmt3a bound to Dnmt3L suggests a model for de novo DNA methylation. Nature 449: 248-251,2007.

54. Stefanska B, Huang J, Bhattacharyya B, Suderman M, Hallett M, Han ZG and Szyf M: Definition of the landscape of promoter DNA hypomethylation in liver cancer. Cancer Res 71: 5891-5903, 2011.

55. Tan AC, Jimeno A, Lin SH, Wheelhouse J, Chan F, Solomon A, Rajeshkumar NV, Rubio-Viqueira B and Hidalgo M: Characterizing DNA methylation patterns in pancreatic cancer genome. Mol Oncol 3: 425-438, 2009.

56. Dimberg J, Ström K, Löfgren S, Zar N, Lindh M and Matussek A: DNA promoter methylation status and protein expression of interleukin-8 in human colorectal adenocarcinomas. Int J Colorectal Dis 27: 709-714, 2012.

57. Radhakrishnan VM, Jensen TJ, Cui H, Futscher BW and

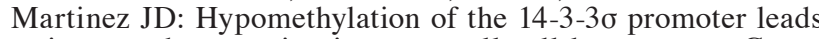
to increased expression in non-small cell lung cancer. Genes Chromosomes Cancer 50: 830-836, 2011. 